RACAR : Revue d'art canadienne

Canadian Art Review

RACAR

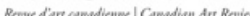

\title{
Here Today and Gone Tomorrow: Jasper F. Cropsey's 'The Backwoods of America'
}

\section{Bernard Bonario}

Volume 9, numéro 1-2, 1982

URI : https://id.erudit.org/iderudit/1074968ar

DOI : https://doi.org/10.7202/1074968ar

Aller au sommaire du numéro

\section{Éditeur(s)}

UAAC-AAUC (University Art Association of Canada | Association d'art des universités du Canada)

\section{ISSN}

0315-9906 (imprimé)

1918-4778 (numérique)

Découvrir la revue

Citer cet article

Bonario, B. (1982). Here Today and Gone Tomorrow: Jasper F. Cropsey's 'The Backwoods of America'. RACAR : Revue d'art canadienne / Canadian Art Review, 9(1-2), 9-20. https://doi.org/10.7202/1074968ar
Résumé de l'article

The Backwoods of America est une des oeuvres principales de Jasper F. Cropsey (1823-1900), artiste de la Hudson River School. Elle fut peinte à Londres en 1858, puis présentée à la Royal Academy. En 1932, le philanthrope W.H. Abbott de London, Ontario, achetait le tableau pour l'offrir, l'année suivante, à l'Université de Western Ontario, afin d'amorcer la formation d'une collection d'oeuvres d'art. En 1981, l'Université se départissait de son tableau lors d'une vente aux enchères à New York. The Backwoods of America fait voir chez Cropsey un intérêt croissant pour le côté rude de la vie dans les régions nouvellement défrichées de l'Amérique. Toutefois son intérêt ne s'arrête pas au reportage objectif. Son tableau renferme des allusions au cycle de la vie et de la mort. Le contraste romantique entre la durée éphémère de la vie humaine et le perpétuel renouvellement de la nature apparaît clairement dans la façon d'opposer, au premier plan du tableau, la pierre tombale, sur laquelle l'artiste a signé sa toile, et une grosse souche d'arbre. The Backwoods of America appartient aux années les plus fructueuses de la carrière de Cropsey et représente cette phase du milieu du $\mathrm{XIX}^{\mathrm{e}}$ siècle où se côtoyent une vision subjective de la nature héritée du romantisme et une approche plus objective et scientifique introduite par les naturalistes.
Tous droits réservés @ UAAC-AAUC (University Art Association of Canada | Association d'art des universités du Canada), 1982
Ce document est protégé par la loi sur le droit d'auteur. L'utilisation des services d’Érudit (y compris la reproduction) est assujettie à sa politique d'utilisation que vous pouvez consulter en ligne.

https://apropos.erudit.org/fr/usagers/politique-dutilisation/ 


\title{
Here Today and Gone Tomorrow: Jasper F. Cropsey's 'The Backwoods of America'
}

\author{
BERNARD BONARIO
}

University of Western Ontario, London

In 1858 , while living in England, the American landscapist Jasper F. Cropsey sent a painting to the annual Royal Academy exhibition titled The Backwoods of America. The picture shown the English public was a large canvas which the artist considered a major work. In the following year it was sold in Scotland to a private collector and did not again become accessible to the public until seventy-five years after its creation, when it was exhibited in another london, this time in Canada.

The University of Western Ontario acquired The Backuoods of America in January, 1933. It was the gift of a local philanthropist, W. H. Abbott. among whose interests was the organization of art exhibits at the city's annual Western Fair. In the spring of 1932, Abbott had solicited loans from art dealers in the hopes of securing appropriate paintings for showing at that year's Fair as well as for potential purchase. He was looking for pictures with agrarian or related themes with which fair goers of the Great Depression days could identify. Yet he wanted pictures fine enough for donation to the city's rising University as part of the nucleus of an art collection.

As fortune goes, a dealcr, Leslie W. Lewis, responded from London, England, with the offer of sending 'a very remarkable picture - a masterpicce of realistic landscapc painting by J.F. Cropsey, N.A. ... entitled Backwoods of America.' Lewis cited early references to the picturc, pointed out its suitability for Abbott's purposes, and described it as 'a large and imposing work. historically interesting, depicting as it does the log cabin, and the pioneer days of the early settler of the American continent.' The philanthropist's appetite was further whetted by assurance that it was 'a fine scenic picture of richly wooded and rugged landscape with striking effect of natural colouring." After brief correspondence between the two men in April and May 1932, the painting was shipped between the two Londons that summer, presumably shown at the fall kair, subsequently purchased by Abbott and presented to the University at the start of the following year. ${ }^{2}$

Although Lewis managed to sell Abbott some pictures of low quality (included among the latter's gifts to the University of Western Ontario), his praise of the Cropsey landscape was inadvertently bestowed on a supcrb work of document-

1 Lence of 7 A pril 1932 from Leslic W. Lewis 10 W.H. Abbott. This and subsequent correspondence between I.ewis and Abboll is in the accession files of the MeIntosh Art Gallery, Lniversity of Western Ontario

2 I.cwis did not own Cropsey's painting at the time he made the initial offer of sending it to (Canada. Since Abbott's letter (22 $\Lambda_{\text {pril }}$ 1932) contained a positive reaction to the offer, I. ewis wrote on the fourth of May 'to say that this day I have purchased the picture "Backwoods of America" by J.F. Cropscy, x.t. It will take a few dats to fix up the frame of the painting which is just slightly damaged ... I.ewis' earlicr letter of 7 April had mentioned a price for the picture, implicit in the follow-up correspondence, but for obvious reasons half of that letter was removed from Abbotts personal documents given to the Lniversits. Lewis' letter of 4 May $193^{2}$ stated his intention of sending the work at a very low valuation to keep down the shipping charges,' suggesting (o) the philanthropist that 'for display or insurance purposes you could value it at say $\$ 2500$ to $\$ 3000$ because the painter used $10 \mathrm{get}$ these prices for his works during his lifetime ...'

The Depression notwithstanding, the $65^{\text {th }}$ Western Fair of 1932 was planned to be the most noteworthy cver. The art exhibition included some fifty (Old Master and Modern paintings borrowed from the I.ewis Gallery, Eaton's Gallery of 'Toronto, the local Nash Galleries, Ottawa's National Gallery and Detroit's Institute of Arts. Cropsey's painting was not cited in revicu's of the show (London Frep Press, 12 Scptember 1932, 7, and 15 September 1932, 9), but perhaps was listed in the exhibition cataloguc, mentioned in the reviews, but as yet unlocated. Abbott's gift, intended as part of a nucleus for the Liniversity's first ant collection, is recorded in the London Free Press of 13 January 1933 and in the University of Western ()ntario President's Report (1 9.32-3.3. 23). 
able authenticity. ${ }^{3}$ Almost ironically, The Backwoods of America is the most significant painting to have passed through Abbott's modest art collection, remaining on public display for several decades and hanging in the University's Lawson Library until about 1970 , when it was transferred to its location in the collections of the University's newly reorganized McIntosh Art Gallery. ${ }^{4}$

3 Long afterwards, Leslie W'. Lewis was to become involved with notorious forgeries of Canadian (iroup of Seven paintings.

4 University of Western Ontario, McIntosh Art Callery, inv. 221 . I studied the painting in storage under unfavourable conditions. Since the completion of my manuscript in March 1979 , the University has deaccessioned The Backinoods of America. Sold Sothebr Parke Bernet. Inc., New York, sale 4583 M (23 April 1981 ), lot 18

5 Modern literature on Cropsey is scant. After his death in 1900 his art became victim of the decline in popularity of Hudson River School painting felt already in the last decades of his working career. Supplanted immediately by the realism of the so-called Ash Can School and subsequent developments in twentieth-century American art, it fell into near obscurity until only recently. During the 19 foos, art historical concerns with the Hudson River School and its individual artists resulted in a series of exhibitions of their works. Serious interest in Cropsey's art was resurrected in the exhibition Jasper F. Cropsey: A Retrospection Viere of America's Painter of Autumn (University of Maryland, College Park, 2 February - 3 March 1 968) and in a larger one, Jasper Francis (iropsey', I 823-1900 (National Collection of Finc $\Lambda$ its, Washington, 29 November 1970 - 3 January 1971). The most thorough study of the artist and catalogue of his works to date is William S. Talbot. Jasper F. Cropsey, $1823-1900$, doctoral dissertation, New York University, $197^{2}$ (published in the series Outstanding Dissertations in ihe fine $\Lambda_{\mathrm{rts}}$ (Garland, New York, 1977, and hereafter citcd as lalbot).

6) Algcrnon Graves, The Royal Academy of Fine Arts: A Complete Dictionary of Contributors and their Irork from its Foundation in I769 10 I904, "I (London: H. Graves \& C.., 1905), 208

T The manuscript of Cropsey's personal account book with sales records for the years $184 j$ to 1868 is in the possession of his descendants in Hastings-on-Hudson, New York, and is published in Talbot, 310-327. The entry for 10 March 1859 reads: "Through W. B. Huggins for my picture "Backwoods" sold in Glasgow for $£ 145-\$ 725.00$.

8 The Crajon, vi (April 18j9), 126.

9 Henry T. Tuckerman, Book of the Artists (New York: G.P. Putnam \& Sons, 1867), 536. The year of the Royal Academy's exhibition is mistakenly given as 18.57

10 Clara E. Clement and Laurence Hutton, Artists of the Nineteenth Century and their Works, 8th ed rev. (Boston: Houghton, Mifflin \& Co., 1896$), 1,173$. The authors rcpeat Tuckerman's erroneous Royal Academy exhibition date.

11 The canvas measures $107.3 \times 177.8 \mathrm{~cm}$. 'Backu'oods of America' / J.F. Cropsey, N. A. (exhibited Royal Academy, I 858) is lettered on the frame beneath the painting in the standard Victorian practice. Written on a card affixed to the back of the frame is: $N^{0}$ I. The 'Backueods' of America / by J.F. Ciropsey / 2 Kensington Gate / Hyde Park - South. This is the address of the studio-house rented by the artist in London during the years 18,56 to 1863 . Its inclusion suggests the label is that of Cropsey from the time of the Royal Academy show or that of the dealer W.B. Huggins, through whom the painting was first sold in Glasgow. Written on the frame's back and overlabeled the same is $V^{\circ} \mathrm{g}$, possibly from an carly owner. Scrawled on the stretcher are the words Dining Room. (On the backing slats are post-1932 labels.
Even though it has been in London, Ontario, almost half a century, Cropsey's The Backwoods of America has remained unstudied until now and is virtually unknown to scholars of nineteenthcentury American art. It was on the London art market in 1932 and could have appeared in a dealer's catalogue, but to my knowledge the picture has not been published previously. ${ }^{5}$ It is recorded as $\mathrm{n}^{0} 74^{1}$ of the paintings shown at the Royal Academy in $185^{6}$ and is entered in Cropsey's account book as sold 10 March $1859 .^{7}$ News of its sale was spread to the United States through the short-lived but influential New York art magazine The Crayon. ${ }^{8}$ Favourable reaction to the picture is noted in an early biography of the painter included in Henry Tuckerman's Book of the Artists, where it is singled out by the critic from among the works Cropsey executed in England as one which attracted the greatest attention. ${ }^{9} \mathrm{Be}-$ ginning in 1879 it was again mentioned in the many editions of Clara E. Clement and I aurence Hutton's Artists of the Nineteenth Century and their Works, where it headed a select list of Cropsey's paintings sent to the Royal Academy during his years of English residence. ${ }^{10}$

The Backwoods of America (Fig. 1) is one of Cropsey's larger oils. Surrounded handsomely by its original gilt frame and protected by the original slat backing, the slightly darkened canvas has suffered minor paint losses only along its lower edge. Several old labels on the work and its frame attest to its source and later history. On the edge of the rock slab in the lower right corner (Fig. 2) are the signature, J. F. Cropsey, and the date, $1858 .^{\prime \prime}$

Work on the picture was started about a year and a half after the artist moved to England. As a youth, Cropsey (1823-1900) had been trained in architecture, but, encouraged by his handling of watercolours, had changed his career to painting. He began in his native New York in $184^{\circ}$ and by the end of the decade, while still only twenty-six, had completed the traditional artistic pilgrimage to Europe. Between the summers of 1847 and 1849 he worked first in London, from where trips were made to paint the English and Scottish countrysides; then, like so many of his predecessors, after travelling through France, Switzerland and northern Italy, he settled in Rome. He lived in Italy for more than a year, but it was the initial contact with the British Isles that gave the greatest stimulus to his art. Landscape sketches done in England and Scotland provided inspiration for works painted in Italy and continued to be sources for Cropsey's pictures after his return 


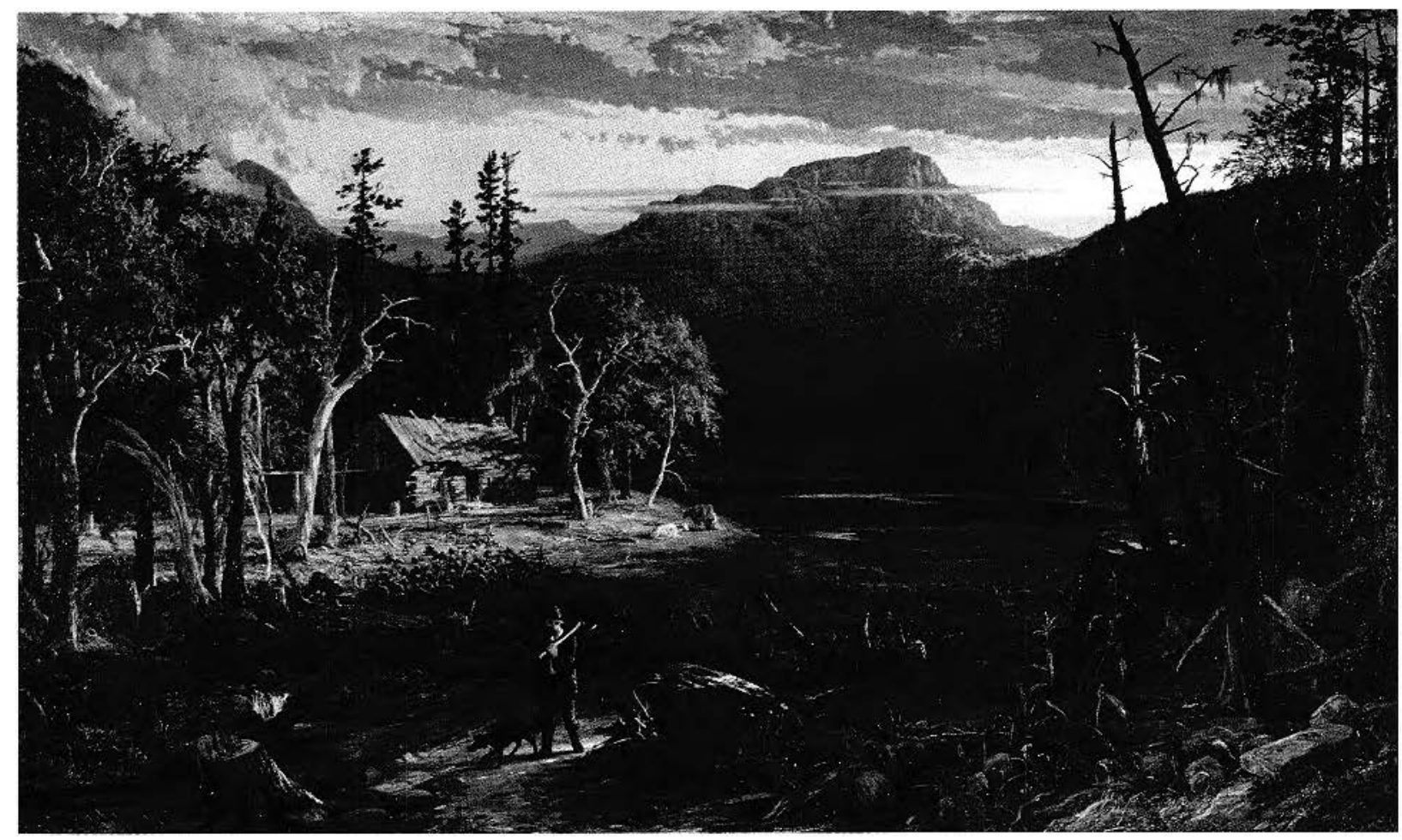

Ficure 1. Jasper F. Ciopsey, The Backuoods of America, 1858 . (Oil on canvas, $107.3 \times 177.8 \mathrm{~cm}$. Fx collection McIntosh Art Gallery, London, Lniversity of Western (Ontario, Inv. 22 1. Private collection (Photo: The I)ctroit Institute of Art)

to the United States. ${ }^{12}$ Although the first half of the $185^{\circ}$ s was only mildly successful for the maturing artist, now 'certified' by European experience, the years between his return to New York in mid 1849 and the summer of $185^{6}$ had not seen all the personal and professional gains he had wished to make. In June $185^{6}$, he again sailed for kingland and soon after arriving set up the Kensington studio at London, where he worked until 1863 .

It was during this second period in England that The Backwoods of America was painted. Though dated $18_{5} 8$, the large canvas was undoubtedly begun in the previous year, for it had to be completed before mid March of $185^{8}$, the deadline for submitting pictures to the Royal Academy's annual summer exhibition in which it appeared. ${ }^{13}$
Cropsey had earlier painted many scenes with mountains, both American and European. Within the setting of the Backwoods picture is a broad mountain range, but the view is not the panoramic one sometimes found in his own landscapes and frequently appearing in those of his American contemporaries. Instead, the background peaks rise up directly across a river and are seen from a low vantage point. The resultant recessional limitation of eyc movement by the

\footnotetext{
12 lalbot, 5 and 75

13 According 10 information received from Miss ConstanceAnne Parker, Librarian at the Royal Academy of Arts, the entry date in the 185 os for the Academy's annual exhibition was mid March, as it still is. Copsev had awo pictures in the 18,8 exhibit. The Barkaroods of Amerion as n" 741 and Brambles as n" 112
} 


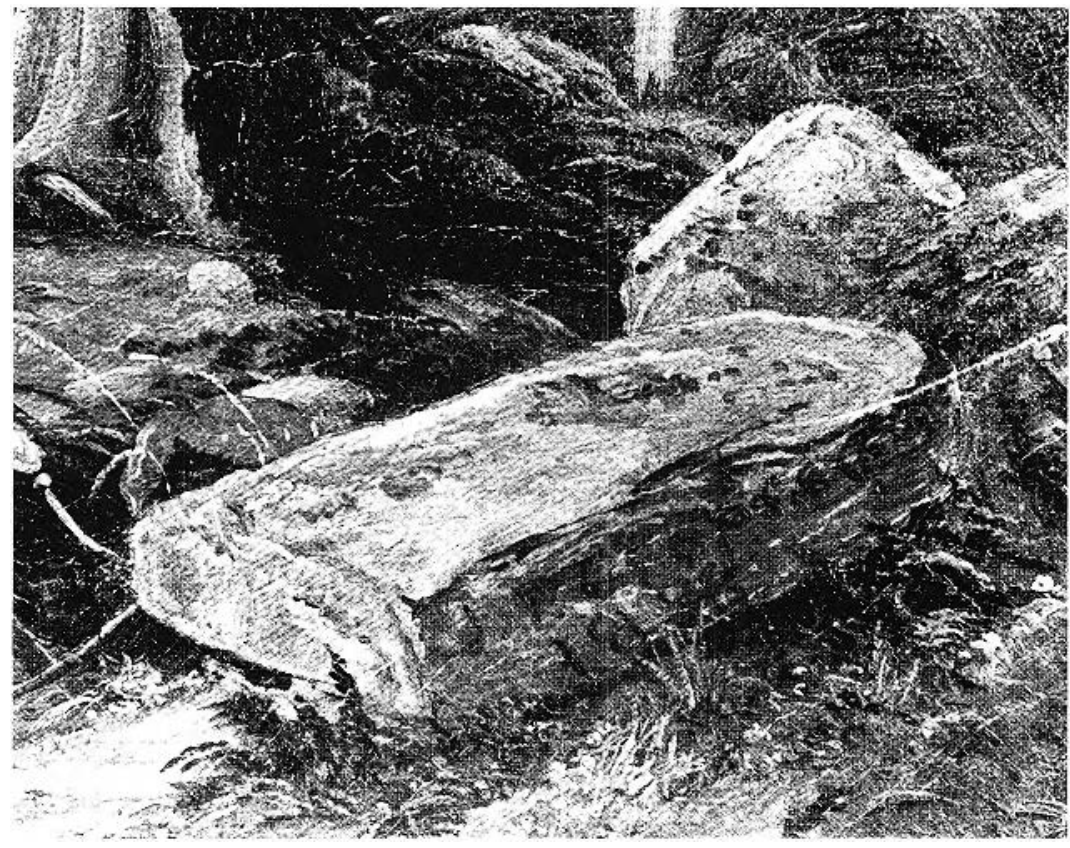

ligure 2. Jasper li. Cropsey, The Backienods of America, with Cropsey's signature on the tombstone (detail) (Photo: MeIntosh Gallery). dense mountains and the confinement of vertical thrust by the dark cloud band extending across the picture's top are effective devices for shifting atlention to the middle distance and foreground, both of which contain figurative elements important to the subject. $\Lambda$ classical grid structure of the principal lines and value patterns, alternating between bands of light and dark, is relicved through the diagonal path of sunlight moving gently from right to left. The overall design is balanced equally between upper and lower halves and between the wo sides. A parallel reciprocity exists between landscape and narative in the subject matter.

The time is daybreak in a valley where darkness and moisture are being dispelled rapidly as the day's labours begin. The carly autumn air is cool and fresh, felt in the decp greens of the mature leaves and shadowy river water. For the moment, the rising sun illuminates only the dark purple and gray highest peak, changing its eastern face to lighter violets and pinks. The thick mists clinging to the slopes at left have ascended on the right, allowing sunlight streaming through a cleft in the distant mountain range to reach the clearing with its $\log$ cabin, animals, and already active dwellers. A narrower shaft of light has penctrated the forests and falls obliquely through the greens and browns of the darkened foreground, striking first the tall, barren trunks at right, then the central boulder and axeman, ending against the large, lower left tree stump.
Amid the surrounding trees the dissipating smoke from the cabin attests to the very early awakening of the settlers. Birds are attracted to the building's roof where one is already perched, while below, the mother in the doorway has just taken her infant to the warmth of the sunny step. An older daughter sits in front with her brother, who whittles a piece of wood, while on the riverbank the eldest girl kncels beside a cow in the necessary task of replenishing the milk supply. Homesteading implements are set around the cabin and its shed. Evidence of reward for the family's hard work is seen in the small garden patch near the house, whilst outside the rail fence the pioneer father takes leave of the group to continue clearing the land. Dressed in purple jacket, blue trousers, gray hat and heavy work boots, and with axe slung over his shoulder, he sets off accompanied by his trustworthy dog. The wo progress among decaying logs of felled trees, numcrous stumps, rocks, and an interesting variety of wild flowers and grasses. On the right grow corn stalks and pumpkins. (For the probable bencfit of his European viewers the artist has exposed the neat rows of kerncls on onc car of corn and has given the several pumpkins of a single meandering vine a ripening orange tinge.) $I t$ is late summer or carliest fall in the backwoods since no autumnal foliage as yet appears. Everywhere in the thin haye soft textures and cool hues predominate, creating an atmosphere with a sense of dewy freshness characteristic of such primcval sites at this hour and scason. 
Implicit in Cropsey's composition, subtleties of coloured lighting and in the rendering of the family, is his move towards a decper intimacy, heightening viewer involvement. Every aspect of the work is carefully controlled, with a concern for detail founded on empirical observation and indicative of the artist's increasing kinship with nature. ${ }^{11}$ Only two years later Cropsey was to paint his largest and most famous work, Autumn on the Hudson River (National Gallery, Washington, D.C.), a picture filled with the brilliant red and golden fall colours which became a hallmark in many of his New England landscapes.

Cropsey had long been interested in the theme of the ruggedness of life on the American frontier. Other pictures dealing with homesteading amid wooded mountains can bc traced back at least a decade, when the artist was in Italy on his first European trip. A small oil called Retired Life. painted in Rome in 1847 , is one of the earliest. ${ }^{15}$ Although the title indicates a different narrative element, the setting is the mountain wilderness of New Hampshire with its cabin and surrounding trees prefiguring those in The Backwoods of America.

Based probably on drawings done just after returning to the United States in 1849 , Cropsey composed Eagle Cliff, New Hampshire in $185^{1}$ (Fig. 3). The loosely painted autumn landscape includes narrative elements of pioneer life which were to culminate in the larger Royal Academy canvas. The jagged mountains are not yet integrated harmoniously with the cabin scene, scale relationships are unconvincing and the figures awkwardly drawn. New York art critics found the foreground details of logs, pumpkins, and sunflowers distracting and disruptive to unity, ${ }^{16}$ problems the artist resolved in The Backwoods of America.

In the seven years in $\Lambda$ merica separating his trips to Europe, Cropsey painted a number of landscapes sct in the mountains of New Hampshire. During this period he scems to have favoured the area when including scencs of frontier existence. In addition to the settings in Retired Life and in the Boston picture he painted Mt. Chocorua in $185^{6}$, also with pioneers. ${ }^{17}$ Thomas Cole had used Mt. Chocorua as the setting in his painting Home in the Woods (ncar Conway, N.H.), for that artist a late, rare genre scene of idyllic frontier life. Cropsey's fellow landscapist, Sanford R. Gifford, painted several versions of Mount Hayes in northeastern New Hampshire near the Maine and Quebec borders. In one version, from the $1860 \mathrm{os}$, a distant riverbank cabin is seen in a panorama from the river, and the mountainous setting is quite close in appearance to that in The Backwoods of America. ${ }^{18}$ After moving to England. Cropsey depicted Mt. Jefferson in the winter of $185^{6-57}$ and continued to use the New Hampshire mountains when showing English audiences the wilds of America, as in Indian Summer Morning in the White Mountains (Currier Gallery of Art, Manchester, N.H.), a significant work exhibited at the Royal Academy in 1857 . New Hampshire mountains appear again the next year bchind the log cabin scene in Eagle Cliff, Franconia Notch, N.II. (Fig. 4) and are likely the setting of The Backu'oods of America. ${ }^{19}$

14 (iropsey followed this direction to its refinement in a group of small, narrowly-focused paintings done of the Isle of Wight in $18.59-60$ (Talbot, 147)

15 Talbot, cat. 22, his fig. 22.

16 In the Nea' York Tribune and Bulletin of Americun Arl L'nom; passages quoted in Talbot, $9^{2}$

17 Talbot, cat. 101 , his fig. 83 .

18 Sce the exhibition catalogue The Hudson River School: American I.andscape Paintings from I 821 lo 1907 (R.W'. Norton Art Gallery, Shreveport, Louisiana, 14 October - 25 November 1973), (at. 1 and 81.

19 Further evidence that Cropsey identified New Hampshire mountain settings with life in the American backwoods comes from interchangeable titling in his personal account book. An entry for February $18-8$. contains a 'Loy Cabin Scene in the Franconia Mountains.' almost certainly the picture now in Raleigh. Iater, on () tober 9. the same painting is referred to as 'Pranconia L.og ('abin.' W'hen finally sold in September of the following ycar. it is itcmized as a picture of 'Backwoods.

The entrics from Cropsey's account book read:

[...] F(t)., 1858 , from 11 r. Henry thornton for picture 'l.og Cabin Scene in the Franconia Mountains' on account $\$ 250.00$.

[...] Oct. 9, 1858 , Henry Thornton, lisq. Iake Ontario Scencry,' exchanged for 'Franconia Log Cahin'\$250.00. [...] Sept., 1859 . ihrough .Mr. Falconer firom I.H. Swift for my picture 'Backwoods', originally for Mr. 'Thornton, $\ell_{59 / 6 / 10}-\$ 294.00$.

Misrcading these, Talbot, 144, states incorrectly that the Backuroods sold September 1859 was a replica of the Backiroods of America exhibited at the Royal Academy in 1858 . the original of which was unknown to him. He was confused about the former's history of sale through overlooking Cropsev's title variations. The error about a replica derives from mistaking the $\$ 25^{\circ}$ mentioned ()ctober 1858 , as a second payment for Log Cabin Scene in the Francomia Mounlans, thus assuming that Thornton paid a total of \$5oo for it (lalbot, cat. 113 ). However, this is contradicted ( $\Gamma$ albot, cat. 104) by claiming the same $\$ 25^{\circ}$ as the price Thornton paid then for Lake' Ontario Sienery.

'Thormton purchased one work only in 1858, Lake' Ontario Solenery, for which he paid on October 9, when the exchange of pictures is noted, either $\$ 25$ (the exact amount he already had on account since February for I.og Calin Seene in the Franconia Mounlains) or a total of $\$ 500$ (since $\$ 25^{\circ}$ is entered with Thornton's name in both February and () tober). He bought nothing in 1859 , when Francomia 


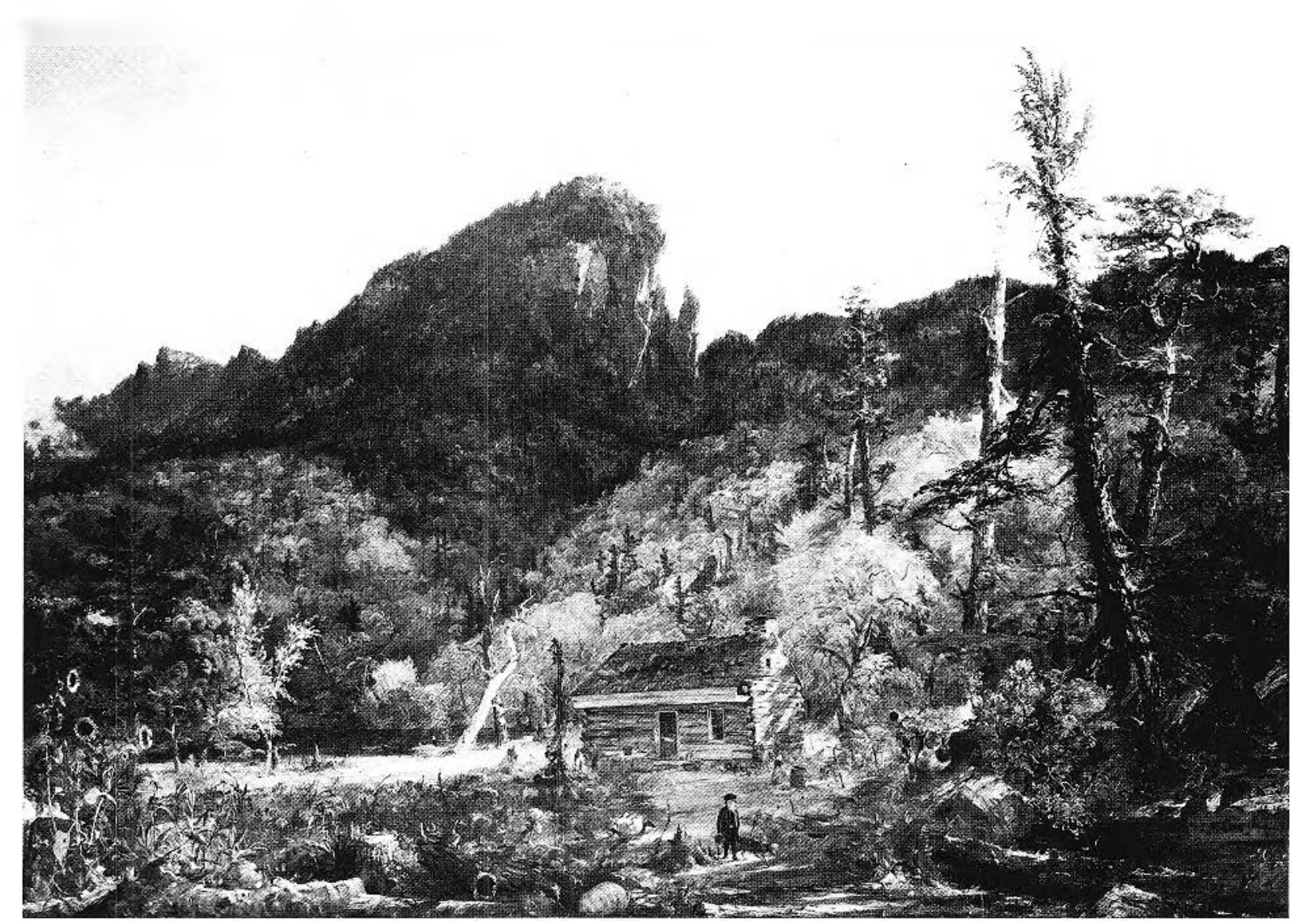

figlre 3. Jasper F. Cropsey, Eagle Cliff, New Hampshire, $18 j 1$. Oil on canvas, $94 \times 134.6 \mathrm{~cm}$. Boston, Museum of Fine Arts, Inv. 47.1190, M. \& M. Karolik Collection (Photo: Museum of Fine Arts).

From the 1840 os onward Cropsey joined fellow: painters of the Hudson River School in numerous trips to favourite spots in New Jersey and in the Catskill and New Hampshire mountains, seeking

Log Cabin, alias Backinoods, in which he had been interested, went to I.H. Swift for $\$ 294$.

A further 'Franconia Mountains' is listed as sold in December 1859,6 , together with another painting for a total of $\$ 5$ oo. However, it camnot be identical with the onc inentioned February and ()ctober 18,8 , since the sale of that picture is clcarly traccable to September 1859 , through Cropsev's convenient use of Thornton's name. Instead, it may be the version of the Raleigh painting described by Talbot as finer, dated 1859 , and on the art market in 1970 . 20 Talbot, 119,126 and 272 , where specific locations and dates of Ciropscy's sketching trips in the northeastern Lnited States are given.

21 Log Cabin Sceme in the Francoma Mounlains, identiliable with the Raleigh picture, is first mentioned in the sales rocords of Cropscy's account book under February of 1858 ; als shown. The Backutoods of America was completed by mid March of that year. ever fresh scencry up into Canada. Following the advice of Asher B. Durand, highly detailed drawings of topographical features and botanical studies were amassed during the warm months for later use in working up finished paintings in the artist's New York studio. Many such visual records were taken by Cropsey to Europe on his second trip in $1855^{6 .}{ }^{20}$ They were the sources for specific features of the landscape settings, probably for details of the narrative objects as well, used in the pictures of North American pioneer life done in the studio at London.

Compared to The Backuoods of America, Cropsey's previous $\log$ cabin paintings are inferior, even though the Raleigh Eagle Cliff, Franconia Notch, ....., also dated 1858 , must have been composed only just before. The possibility exists that the two canvasses were developed or finished simultaneously. ${ }^{21}$ In both, details of the log cabin and shed, of the flanking dead trees and of the 


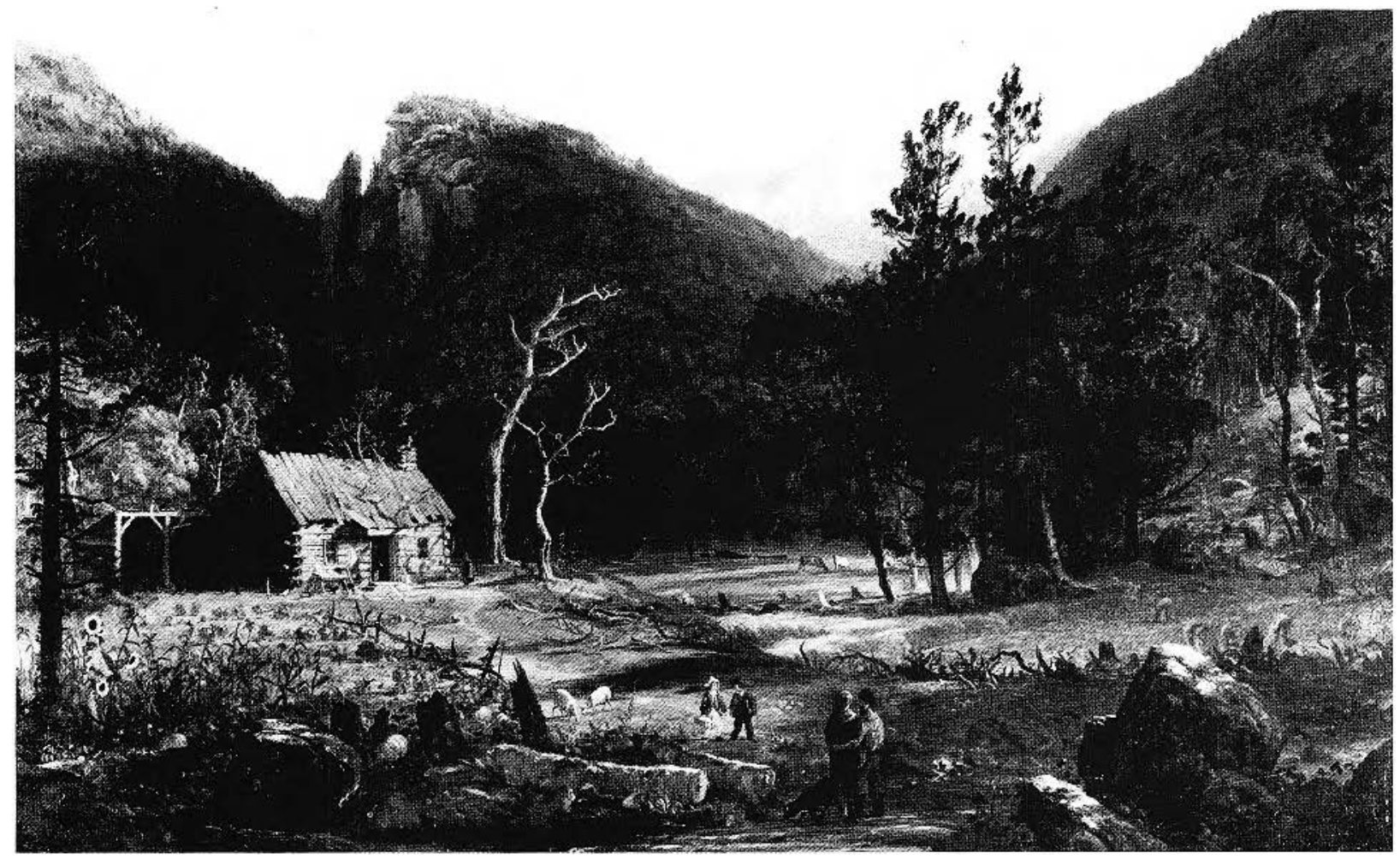

Figure 4. Jasper F. Cropsey, Eagle Cliff, Franconia Notch, v.11. 1858. Oil on canvas, $61 \times 99 \mathrm{~cm}$. Raleigh, North Carolina Muscum of Art, Inv. 52.9.9 (Photo: North Carolina Museum of Art).

garden patch with its rail fence are closely alike, while the figures of mother and child at the doorstep arc identical. The Raleigh picture alters the monotony of the Boston composition by shifting the cabin from dead centre to left, causing the artist to forgo topographical accuracy in reversing the jutting rock formation of Eagle Cliff to maintain alignment with the building's doorway. ${ }^{22}$ 'The sharp light contrasts in the Boston landscape are somewhat softened in the later Raleigh painting, bringing it closer still to the atmospheric rendering in The Backwoods of America. Still present, however, are the clumsiness in scale relationships and in figure drawing, lifelong weaknesses in Cropscy's art. Comment that 'the foreground details of vegetables should not only be pictorially but aesthetically subordinate ... in the presence of this towering grandeur of mountain, ${ }^{2: 3}$ a criticism originally applied to the Boston painting, remains unheeded in the artist's log cabin scenes until the Royal Academy canvas of 1858 .

In his dissertation on Cropsey, William S. Talbot concludes that some of the pictures of 1858 are quite aw'kwardly painted or else uninspired in composition, adversely judging the Raleigh painting of that year as a rclapse from lormer attainments. ${ }^{24}$ Wide variation in the quality of Cropsey's art was in any event remarked from its beginnings by art critics in England and America. Henry Tuckerman pointed this out most clearly in 1867. the midpoint of Cropsey's career, offering an explanation which must have an important

22 According to 'Talbot, 142 and cat. 52 , of all Cropsey's Eagle Cliff pictures that in Boston is the most accurate topographically and the peculiar rock formation is not visilble from the other side.

23 Quoted in Talbot, 92, after the Bulletin of Amorican Art Umion (Mav 1851$)$.

24 Talbot, $141-142$ 
place in all modern reassessments of the artist: 'Cropsey is sometimes careless and crude. His sense of beauty and truth in nature are eloquently apparent in his best efforts; but his executive power seems unequal, which is probably owing to the inequality of working moods incident to irregular health. ${ }^{25}$ The contrast between the two log cabin scenes of $185^{8}$ is therefore exemplary.

Tuckerman's biography informs us that Cropsey was of very delicate health from childhood, later working in such intervals as health allowed. While in England he had been sick since the latter part of 1857 ; his painting was affected intermittently until the middle of $1860 .{ }^{26}$ The Backwoods of America was created during a time of convalescence; when it was finished in early 18,5 , Cropsey sent only a lesser work titled Brainbles to accompany it in the Royal Academy show. To represent himsclf in the United States that year he sent two minor pictures to the annual exhibition of the National Academy of Design, where his landscapes had been shown over the past fifteen years. Critical reaction to the latter is summed up by a reviewer of the show: "Cropsey is scarcely represented this season - two small works, with one, Janetta Falls, an admirable study, being the only warrant for his name. ${ }^{27}$

The fact that Cropsey sent fewer pictures to art exhibits in 1858 , combined with Talbot's obscrvation that some of the ones painted then are noticeably lower in quality, is partly explained by the artist's lingering illness. It is also possible that he considered The Backwoods of America significant enough to allow lapses in works he deemed less worthy of prolonged attention, most particularly at a time of limited physical energy. That he viewed it as a major piece is suggested by the size of the canvas, among the artist's larger works, ${ }^{28}$ and by its selection as the chief painting exhibited during the year, ${ }^{29}$ as well as by the overall quality.

25 Tuckerman, 533

26 The artist refers 10 his illness in a letter 23 Novenber 18.57 sent to a patron in the Lnited States and now at the Walker Art Center, Minncapolis. For the extent of Cropscy's illness during these ycars and the effects on some of his paintings, see lalbol, 1/2-146.

27 The Cravon, v (May 18, 8 ), 147

28 Of the 245 works catalogued by Talbot less than a dozen are of approximatcly equal or greater dimensions.

29 For a chronological exhibition record of Cropscy's works, see Talbot, $27(9)-309$.

30 See Cropsey's sale records for $1847-48$ and $18,56-63$ as compiled in lalbot, $310-327$.

31 Asher B. Durand. 'Lctters on Landscape Painting', The Crayon, 1,1855 (reprinted in part in John W. McCoubrey, American Art 1700-1960; Sources and Documents [Englewood Cliffs, N.J.: Prentice-Ilall, 1965$], 110-115)$.
The $\$ 725$ it was sold for was also one of the highest sums he received for a single painting while abroad..$^{30}$

Throughout his career Jasper Cropsey painted numerous smaller pictures inspired by his fondness for nature. Some were landscape inventions while others were studies of the topographical features, atmospheric conditions, and native plants of specific sites. In most the naturalistic and the romantic were combined. Lifelong health problems scem at times to have affected his painting techniques, which ranged from faint brushwork of smoothly finished surfaces or coarser but effective passages in the best pictures to, in the worst, uninterestingly repetitious areas of paint on crudely drawn forms.

In The Backuoods of America the pigment is applied carefully in a series of oil layers built to an overall even surface, the glazing allowing nuances in lighting necessary to render the described atmospheric effects through the academic method prevailing before the innovations of the Impressionists. In England Cropsey was able to observe opaque slashes of paint in landscapes by Constable and the freedom of technique in Turner's expansive paintings, but these lessons came to fruition in other works. Here the similarities are with the mid-century pictures of his American contemporaries in the Hudson River School, cven if Cropsey's extensive areas of fluidly applicd paint and apparent brushwork are closer to Cole than to the new ideal published shortly before in 18,55 by the school's theorist, Asher B. Durand. ${ }^{31}$ Yet the brushwork is less vigorous and inclusion of broad passages limited by comparison to many of the artist's other works, even those of the same date. The sky and mountains are free of brush marks, but the trunks, foliage, and narrative objects are depicted alike with short, active strokes and with only slight textural differentiation; greater broadness is used in the river and shadowed sections of the middle distance.

There is an obvious correspondence between the higher levels of artistic merit in composition and technique and those pictures, large or small, the artist considered important. In the Royal Academy Backwoods the narrative components occupy bigger areas than is usual in Cropsey's landscapes. They are the products of a developed interest in theme and are better drawn and more refined in scale than is often the case with such 
elements, particularly among his abundant small works. Commensurate with this is the painting technique.

The subtle contrast in the painting technique echoes the balance of the simplificd composition and that of the subject's dual interests of landscape and narrative. While working in Italy very early in his career, between 1847 and 1849 , Cropsey varied his style according to subject matter. Images of the serenity of time-worn Italian landscapes were painted in a meticulously finished technique while those of the still raw American wilderness were given an appropriately rougher treatment through vigorous brushwork, reflecting the artist's emotional reaction to the opposing subjects rather than their actual appearances. ${ }^{32}$ The equilibrium of painting technique in The Backwoods of America underscores the expression of Cropsey's psychological attitudes toward the enduring grandeur of still mountains at a late summer's dawn and the temporary hardships of man's active existence below in such way that Nature and Man are given mutual significance.

Now major American contemporaries of Cropsey (Frederic E. Church and Albert Bierstadt) in their depictions of nature's grandeur usually reduced Mankind to a minute observer of the landscape's immensity. The figures in The Backwoods of America are, however, not adjuncts to a rendition of nature, while, conversely, the landscape is not simply a backdrop for the narrative. Rather, there exists a unity which interweaves interest in the rugged landscape at this time of day with the narrative necessary to the condition 'backwoods,' where men and women have gone to live and work.

Though created in a studio a continent away, both the landscape and narrative derive from personal observation, which lends genuineness to the imagery. Only the pumpkins and corn seem contrived, but they were obligatory symbols of the Americas for European audiences. The effects of dawning light and rising mists and the renderings of the mountains and woods, as well as the suggestion of vegetal growth on the now placid river, are optically convincing, and various wild plants are drawn with botanical accuracy. Naturalistic observations within the narrative include the wispy smoke curling in the freshness of carly morning air, the unidealized life stages of the trees, the hungry birds above the cabin, the baby being placed on the doorstep, and the children entertaining themselves and assisting with work.
However, Cropsey's interest in factual accounts of elements in the landscape and narrative is countered, if not outweighed, by his use of metaphors tied to moral concerns and influenced by Romantic literature. Tuckerman noted such tendencies in the works exhibited for a large sale just before Cropsey embarked for England in 1856 : 'Besides a remarkable tact in color and a true sense of the picturesque, a moral interest was frequently imparted to his landscapes by their historical or allegorical significance, in which as in other respects he reminded his countrymen of Cole. ${ }^{133}$ In our picture, living creatures and inorganic matter share their material existence before God's witness. The provisions extracted from the land are offset by the family's fear of divinely created Nature and reverence for her as moral instructor, qualities alrcady threatened in the industrial capitals of Europe and in the rapidly expanding cities of the Amcrican Northeast.

Cropsey's views are manifested clearly in several significant places in the painting, all allusions to life and death. The family's existence in the backwoods is made evident by the log cabin, the protector of human life. It is a shelter wrought from the woods whose mature trees must yield to man's needs, revealed in the prominent foreground stump. Man's interuption of a life cycle in nature serves as a reminder of the boundaries of his own existence. Death, ever present, and nearer in the precariousness of the wilderness, is identifiable with the two overt, twisted and barren trees which, directly behind the paterfamiliar axeman, sinisterly bracket the dwelling place and hang over the children below.

On the right side of the painting Cropsey has particularized his own membership in the universal drama. Beneath the, to borrow a description from Cole, lofty and scathed trunks on American soil lies a rock slab hewn into the shape of a tombstone, upon which are the artist's signature and the year (Fig. 2). Symbols of human transience are again confronted by an image of regenerative life in the thriving vine stemming from under the slab. The Romantic contrast between the ephemeral existence of individual human life and Nature's continual renewal is clear in the purposeful placement of the inscribed

32 Talbot, 5 . For an interesting parallel vacillation in the litcrary arts see Ernest II. Redekop, 'Picturesque and Pastoral: Two View's of Conper's landscapes,' The Cinadian Rerriere' of dinerican Shudees, vill (Fall 1977 ), 184-205.

3.3 Tuckerman, $532-33$. 
tombstone and the large tree stump in opposite corners of the picture's foreground. ${ }^{34}$

Cropsey's most recent bout with poor health and his fears over the deteriorating economy, epitomized in the Amcrican panic of 1857 and heightence by the artist's lifelong financial problems, could well have induced a period of extended melancholy. In a despondent letter of 23 November 1857 which (Cropsey wrote to a patron in the Lnited States about his cumbersome illness, which required much care and necessarily prevented him from working, he continued: 'What a panic you have had in America and how' much the artists must suffer from it. 'The effect on art is almost as great here. I hear of many complaints. Many of the large firms have failed here in great part through American losses, men liberal patrons of the arts - I fear I must also be a loser. ${ }^{35}$ In addition, Cropsey anticipated that his recent settlement in England would be a lengthy one, and a mood of homesickness might have invaded him at the time of his expatriation. ${ }^{36}$ His most successful pictures for the English were those of his native scencry; the spirit of Americanism in the Backwoods canvas, regardless of the absence of Cropsey's usual autumnal foliage, went unsurpassed.

It was during the 1850 os that Cropsey broadencd his subject interests beyond landscapes into allegorical and litcrary paintings and began to produce works for books. In $185^{\circ}$ he provided illustrations for Bunyon's Pilgrim's Progress, had a landscape engraved for The Home

34 (I. Nicolai Cikovsky, Jr., "The Ravages of the Axe: The Mcaning of the Tree Stump in Ninetecnth-Contury American Art, Ait Bulletin, L.XI (1)ecember 1979). 611-626. which appeared after the present article was completed.

35 Manuscript at the Walker Irt Center, Minneapolis; quoted in Talbot, 132-33

$36 \mathrm{I}$ was reported in The Cranon of February 18,6 that Cropsey's move to England, projected for that summer, was intended to last several years. This is repeated in Tuckerman's biography. Talbot, chapter 4 , has shown that once abroad, Cropscy spent a great deal of moncy furnishing and remodelling his studio-house and establishing a high social life and that when he departed in 186.3 , he clearly expected his residence in lingland to continue after only a vear or two in America.

37 Letter of Cropsey to ' $\mathrm{M}$ ', 12 May $185^{2}$ (manuscript with the artist's descendants in Hastings-on-Hudson. New York); quesed in the thorough discussion of the two paintings in Talbot, $106-111$ and cat. 61

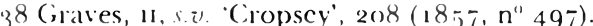

39 The Poets of the West (I.ondon: Sampson Low, Son \& Co., $18-59) .66$. Payment for this 'drawing on wood' is recorded in Cropsey's account book under 25 October 1858

10 The figures must have appealed (o) Cropsey as they appear to have been used again the next year in 11 inter. North conzecy, NH. (l'albot, cat. 123 , his fig. 112).
Book of the Picturesque of $185^{2}$, and, in 1857 , drew illustrations for the poems of Edgar Allen Poe and the Irishman Thomas Moore. At the beginning of the decade, with renewed inspiration from Cole's works, he invented such laboured compositions as the Spirit of War and Spirit of Peace, about which he wrote lengthy explanations that quoted passages from Sir Walter Scott. ${ }^{37}$ Other paintings like the ${ }_{18} 85^{8}$ Genevieve, based probably on Coleridge's poem, adhered closely to sources in Romantic literature. Associations with poetry wcre made by Cropsey in even his pure landscapes. The catalogue entry for the first major picture he exhibited at the Royal Academy after his move to England reads: 'An Indian summer morning in the White Mountains, America. "Filled was the air with a drcamy and magical light, etc." - Longfellow. ${ }^{138}$

In 1858 Cropsey illustrated Charles Fenno Hoffman's pocm 'Room, Boys, Room' (Fig. 5), published shortly after in The Poets of the West, a selection of favourite American Romantic poems for English readers. ${ }^{39}$ The theme of the poem and Cropsey's pictorialization are related to The Backuoods of America, finished earlier that year. Hoffman celebrates the freedom of the American hunter's vast domain while lamenting its inevitable end:

And still sung the hunter - when one gloomy day, He saw in the forest what saddened his lay, A heavy-wheeled wagon its black rut had made, Where fair grew the greensward in broad forest glade -

He whistled to his dog, and says he, 'We can't stay; I must shoulder my rifle, up traps, and away;' Next day, 'mid those maples the settler's axc rung. While slowly the hunter trudged off as he sung, "Ihe world's wide enough, there is room for us all; Room enough in the greenwood, if not in the hall. Room, boys, room, by the light of the moon, For why shouldn't every man enjoy his own room?'

In Cropsey's quite literal illustration, the hunter and his dog have merely switched roles with the similarly posed pair in the Backwoods canvas. ${ }^{40}$ The entire scenc seems like a prelude to the settlers' subsequent development visible in the painting. The poem immediatcly following Hoffman's in the book is one every American schoolboy was to recite, George P. Morris' 'Woodman, Spare that Tree.'

Like others of his countrymen, Cropsey was concerned about the outcome of the disappearing wildcrness. Much earlier, fellow artists in the Northeast werc already alarmed. At the end of his 1835 lecture on American scenery, Thomas 


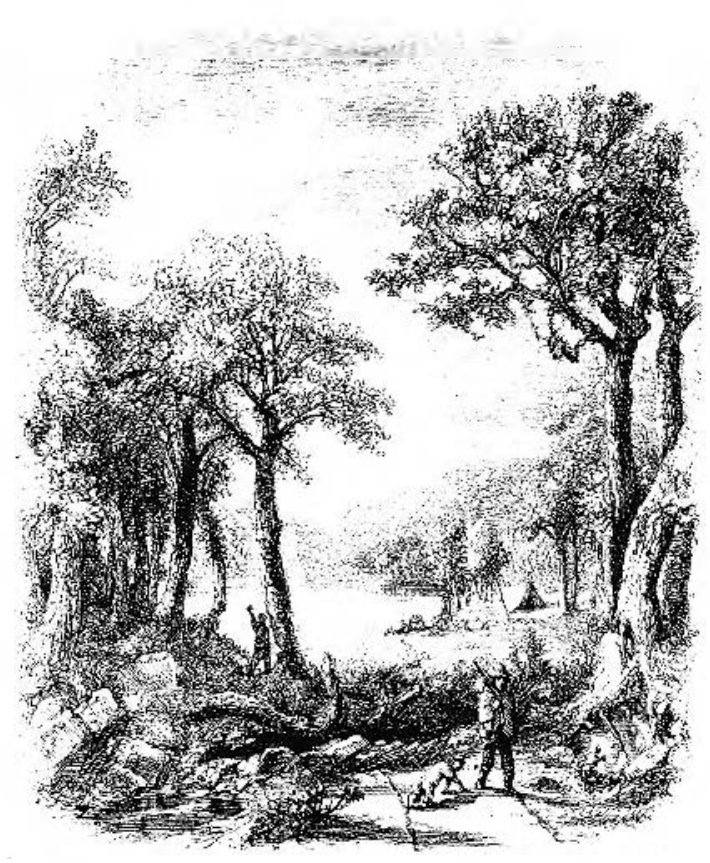

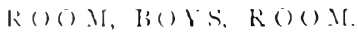

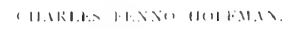

Figurk: 5. Jasper F. Cropsey, engraving for Charles Fenno Hoffman's poem 'Room, Boys, Room' from The Poets of the II'est (London: Sampson Iow, Son \& Co.. $1859)$.

Cole had stated: 'I cannot but express my sorrow that the beauty of such landscapes is quickly passing away - the most noble scenes are made desolate, and oftentimes with a wantonness and barbarism scarcely credible in a civilized nation. ${ }^{.41}$ Cropscy had been made aware of the problem at the very beginning of his career as a painter. A review of one of his 1847 landscapes had praised his fidelity to nature and had pleaded for the widespread recording of the natural state of the American wilderness beforc it was destroyed by 'the axe of civilization. ${ }^{142}$ In The Backuoods of America Cropscy has recorded instcad the death of primordial nature, which, along with most Americans, he was forced to accept as the incvitable if regrettable price for development. In $18 j$ j he had been able to sce American settlements up to Ann Arbor, Michigan - the farthest west he is known to have travelled - when his friend Dr. Henry Tappan, recently appointed president of the University of Michigan, invited him to paint the burgeoning campus there and its newly built astronomical observatory. ${ }^{43}$ A paradoxical view involving desire for benefits from man's progress and for preservation of nature had become common by the 185 os among artists and writers, many of whom belonged to Cropsey's circle of wcll-educatcd friends in New York. ${ }^{44}$

The combination of romantic and scientific interests in The Backuoods of America is an inevitable outgrowth of developments within Cropsey's life and career which are inscparable from larger issues of his century. Born on Staten Island, he was educated in a rural school and later in New York City. Accustomed to making summer sketching trips into the surrounding frontier and assisted increasingly by railroads, Cropsey witnessed continually the contrast between his country's largest urban centre and places still frec of ever advancing industrialization. From the beginning of his career he had known, too, differences between American and Furopean societics, an awareness facilitated by the cnormous growth in intercontinental travel. The character and rapidity of such changes and the psychological conflicts they engendered in the wake of the Industrial Revolution were a widespread and fundamental impetus behind much Romantic art and literature of the first half of the nineteenth century. Important expressions of European Romanticism were in pictures with literary or historical subjects as well as in landscapes, while in America the absencc of a long literary or historical tradition of its own narrowed the best of Romantic images to art inspircd by experience of the land itself.

$\Lambda$ s part of the Hudson River School, Cropscy was among the first Amcrican painters whose art derived from personal responses to the uniqueness of their native landscape. At the beginning

41 Thomas Cole, lecture on 'American Scenery' at the New York Lyceum, o May 1835; published as 'Essay on Amorican Scenery', The American Monthly Magazine, Now Series, 1 (Januarr 1836), 1-12 (reprinted Mic(coubrev, (98-110). 42 Literary World (15) May 1847), quoted in Talbot. 41. 43 Talbot, cat 83 .

44 lior a discussion of this problem affecting American artists in the first half of the nincteenth contury, see Barbara Novak, 'The Double-Edged Axe.' Alt in America. 1.xiv (January/lebruary 1976$), 45-5$ ) 
of the nineteenth century Americans had been content with mere topographical renderings of the land. In the second quarter of the century Thomas Cole and lesser masters formed the first generation of painters to interpret the landscape - mainly the Northeast - in ways parallel to Emerson's moral didacticism and William Cullen Bryant's poetic metaphysics and romanticism. Cropsey began his career in the final years of Cole's life and belonged to the second generation of the Hudson River School whose members reached maturity at mid-century, a time when existing romantic ideals were being challenged by the scientific enquiries of naturalists.

All in all, The Buckuoods of America was created during the best years of Cropsey's career, corresponding roughly to the third quarter of the nineteenth century. There are few instances in which the artist was successfully able to integrate genre scencs and large-scale figures with his landscape compositions, so the Backwoods picture

15 I.etcer of Ciropsey to 'M' ( 12 May 1852 ), quesed in Talbot. 108 . emerges as one of the best. It is representative of the mid-century encounter between a subjective, romantic approach to nature and the more objective, scientific one, leading to a basic confrontation in nineteenth-century American painting. In a letter of $185^{2}$, Cropsey, in seeking to clarify his new interest in allegory, wrote that artists should create intellectual expressions and should employ a style balanced between high finish and spontaniety, one intended to assist the beholder in experiencing the same feclings as those which inspired the picture. He pointed out that he welcomed imagery which gave him greater opportunity for thought and study than the everyday kind of art. ${ }^{45}$ Though never abandoning his attachment to nature, at this youthful point his model was obviously the recently deceased Cole (d. 1848 ), who had rejected the primacy of nature and held idea above imitative art. More than a vestige of such a view remained after Cropsey moved to lingland. It was still meaningful to the painter when he sent the just completed Backinoods of America to the Royal Academy in the spring of $185^{8}$.

\section{RÉSLMÉ}

The Backuroods of America est une des (xuvres principales de Jasper F. Cropsey (1823-1 (9oo), artiste de la Hudson River School. Elle fut peintc à $\mathbf{l}$ ondres en 18,8 , puis présentée à la Royal Academy. En 1932 , le philanthope W.H. Abbott de london, Ontario, achetait le tablcau pour l'offrir, l'année suivante, à l'Université de Wcstern (Ontario, afín d'amorcer la formation d'une collection d'cxuvres d'art. En 1981 , l'L niversité se départissait de son tableau lors d'une ventc aux enchères à New York. The Backu'oods of America fait voir chez Cropsey un intérêt croissant pour le côté rude de la vic dans les régions nouvellement défrichées de l'Amérique. Toutefois son intérêt ne s'arrête pas au reportage objectif. Son tableau renferme des allusions au cycle de la vie et de la mort. I.e contrastc romantique entre la durce éphémère de la vic humaine et le pcrpétucl renouvellement de la nature apparaît clairement dans la façon d’opposcr. au premier plan du tableau, la pierre tombale, sur laquelle l'artiste a signé sa toile, el une grosse souche d'arbrc. The Backüoods of America appartient aux années les plus fructueuses de la carrière de Cropsey ct représcnte cettc phase du milicu du Xıx" siècle où se côtoyent une vision subjective de la nature héritće du romantisme et une approche plus objective et scientifique introduitc par les naturalistes. 